\title{
EL ESTADO: SUB-PRODUCTO DE LA COMPETENCIA POR EL LIDERAZGO POLITIICO. APORTES WEBERIANOS PARA REPENSAR LA POLITIZACIÓN DE LAS BUROCRACIAS
}

\author{
Jonás Chaia De Bellis ( ${ }^{()}$ \\ Universidad de Buenos Aires / CONICET
}

\section{RESUMEN}

El problema de la autonomía de la burocracia y su posible politización atraviesa varias discusiones actuales. En el presente artículo proponemos una discusión teórica que cuestiona el punto de partida predominante de estos estudios, esto es: la exogeneidad estatal respecto de los procesos políticos que permitiría la colonización política de la administración pública. Por el contrario, y «haciendo regresar a Weber al primer plano", sostendremos aquí que es posible observar al aparato estatal como resultado de los intercambios materiales que los líderes, amenazados por la competencia política, deben realizar para sobrevivir en el poder.

\section{PALABRAS CLAVE :}

Estado, burocracia, autonomía, supervivencia política, liderazgo.

(•)E-mail: jonas.heliogabalo@gmail.com

\section{ABSTRACT}

The problem of bureaucratic autonomy and its possible politicization goes through several current discussions. In this article we propose a theoretical discussion that questions the predominant starting point of this works -i.e. the State's exogeneity regarding political processes that would allow the political colonization of public administration. On the contrary, and "bringing Weber back in", we will argue here that it's possible to observe the State as a result of material exchanges that leaders, threatened by political competition, must make to survive in power.

\section{KEY WORDS :}

State, bureaucracy, autonomy, political survival, leadership.

RECEPCIÓN: $10 / 10 / 15$

ACEPTACIÓN FINAL: 07/03/16 